Joanna Ciesielska-Klikowska

Łódź

\title{
WSPÓŁCZESNE NIEMCY WIDZIANE OKIEM FILMOWCÓW - FILM NIEMIECKI W XXI WIEKU
}

„Kino jest miejscem połączenia, gdzie obrazy i dźwięki spotykają się ze sobą, gdzie ekran spotyka publiczność a filmy łączą i różnią się między sobą. Wszystko jest kinem" ${ }^{\prime 1}$. Ta myśl słynnego francuskiego reżysera Jeana-Luca Godarda, współtwórcy silnego prądu w kinematografii europejskiej Nouvelle Vague - Nowej Fali - stała się mottem dla wielu niemieckich twórców na przełomie XX i XXI wieku. Na przestrzeni ostatnich kilku-, kilkunastu lat reżyserzy z Republiki Federalnej Niemiec poszukiwali sposobu ukazania najważniejszych problemów współczesnych Niemiec i ich najnowszej, często niezwykle bolesnej historii, jako połączenia między wymagającym dla widza obrazem a ciekawym dźwiękiem i montażem, który przykuwałby uwagę odbiorców także spoza niemieckiego kręgu kulturowego.

Zainteresowanie Niemców ich dziejami i problemami, które dotyczą wszystkich grup społecznych, jest niezwykle duże. Państwo niemieckie, które jako jedno z pierwszych doceniło wagę wynalazku braci Maxa i Emila Skladanowskich, którzy 1 listopada 1895 roku w swoim rodzinnym Berlinie zaprezentowali pierwsze urządzenie służące do wyświetlania filmów, tzw. „bioskop”, z wielką uwagą śledziło i wspierało przedsięwzięcia zdolnych, niezwykle wizjonerskich twórców, którzy w kolejnych latach zrewolucjonizowali zarówno europejski, jak i światowy przemysł rozrywkowy. I choć dziś waga niemieckiej kinematografii nie jest już tak duża jak w złotych latach dwudziestych zeszłego stulecia, gdy triumfy święciły kultowe dziś filmy ekspresjonistyczne Roberta Wiene czy Fritza Langa, a następnie legendarne dzieła Josefa von Sternberga, to jednak niemiecka sztuka filmowa pozostaje niezwykle ważnym elementem światowej \footnotetext{
2009.

${ }^{1}$ Szerzej: R. Brody, Everything is cinema: the working life of Jean-Luc Godard, Picador
} 
kultury. Jest ona także niezmiernie bogata i ciekawa, a tematyka w niej poruszana koncentruje się $\mathrm{w}$ ostatnich latach na kilku obszarach. Jak podkreśliła w swoim wystąpieniu otwierającym przegląd Nowe Kino Niemieckie na łódzkim festiwalu Cinergia w listopadzie 2011 roku Maria Malatyńska, autorka książek i pedagog w Państwowej Wyższej Szkole Teatralnej w Krakowie „Niemcy boją się terroryzmu, Turków, kapitalistycznego wyścigu szczurów, globalizacji i odradzającego się faszyzmu"2 i to właśnie te strachy stanowią najważniejsze problemy podejmowane w niemieckiej kinematografii.

Do najważniejszych obszarów tematycznych zaliczyć należy:

- problematykę najnowszej historii Niemiec - okres narodowego socjalizmu i podziału Niemiec w latach 1949-1990, a w szczególności historię Niemieckiej Republiki Demokratycznej;

- zagadnienia integracji wielokulturowego społeczeństwa niemieckiego;

- kwestie współczesnych problemów i wyzwań stojących przed niemieckim społeczeństwem.

Analizując kinematografię zza Odry z początku lat dwutysięcznych można odnieść wrażenie, że kino niemieckie na swój czołowy temat wybrało rozliczenie z bolesną i trudną przeszłością. Przykładem tego zainteresowania stały się przede wszystkim filmy opowiadające o czasach III Rzeszy - „Nigdzie w Afryce” z 2001 roku, czyli poetyckie studium wrażliwej kobiety, zmuszonej do opuszczenia własnej ojczyzny wraz z mężem i dzieckiem z powodu represji wobec ludności pochodzenia żydowskiego w reżyserii Caroline Link, uhonorowane w 2003 roku Oscarem dla najlepszego filmu nieanglojęzycznego; przyjęty z wielkim zainteresowaniem, ale i wywołujący wiele kontrowersji „Upadek" Olivera Hirschbiegla z 2004 roku, będący poruszającą fabułą o ostatnich dnia życia Adolfa Hitlera i jego świty, której scenariusz oparto na wspomnieniach sekretarki Führera Traudl Junge; trudny choć zarazem bardzo wzruszający obraz "Sophie Scholl - ostatnie dni" Marca Rothemunda z 2005 roku, z niezwykłą rolą Julii Jentsch, który opowiada o studentach uniwersytetu w Monachium, przywódcach antyfaszystowskiej organizacji „Biała Róża”; a także niemiecko-austriacka koprodukcja „Fałszerze” Stefana Ruzowitzky'ego z 2007 roku, opowiadająca prawdziwą historię operacji fałszowania pieniędzy i dokumentów przez robotników żydowskich w obozach koncentracyjnych na zlecenie ich nazistowskich oprawców, która w 2008 roku wyróżniona została nagrodą Amerykańskiej Akademii Filmowej dla najlepszego filmu nieanglojęzycznego. Wszystkie wymienio-

${ }^{2}$ M. Nowicka, Kino $z$ Niemiec, Niemcy $w$ kinie, http://www.film.com.pl/?q=node/5875, data odczytu (12 listopada 2012). 
ne filmy stanowiły wyzwanie zarówno dla ich twórców, jak i dla niemieckiego społeczeństwa, które wprawdzie jak żadne inne w Europie czuje się odpowiedzialne za tragiczną historię pierwszej połowy XX wieku i nie obawia się rozliczenia z trudnymi tematami, ale i krytycznie spogląda na każdą próbę opowiedzenia o latach 1933-1945³.

Dzieła te zyskały rozgłos zarówno w Republice Federalnej, jak i poza jej granicami wskazując, iż spojrzenie w lustro bywa czasem bolesne, ale i konieczne. Niemniej nie każda ekranizacja otrzymała przychylną ocenę krytyków i widzów, a do grona filmów podejmujących tematykę okresu narodowego socjalizmu należy również zaliczyć te mniej udane - komedię „Adolf H. - Ja wam pokażę" Daniego Levy'ego z 2007 roku, opowiadającą historię przywódcy III Rzeszy w ostatnim okresie jego rządów i przedstawiająca go jako groteskową postać, niezdolną do wykonywania swoich obowiązków i pogrążoną w depresji, z której uleczyć ma go Adolf Grünbaum, nauczyciel sztuki aktorskiej żydowskiego pochodzenia; praktycznie nieznany w Polsce film "John Rabe", będący niemiecko-francusko-chińską koprodukcją w reżyserii Floriana Gallenbergera z 2009 roku, opisującą losy mieszkającego w Chinach niemieckiego przedsiębiorcy, funkcjonariusza NSDAP Johna Rabe, który uchronił ludność chińską podczas masakry nankińskiej w latach 1937-1938; oraz przyjęty z dużym zainteresowaniem, ale i wywołujący dyskusje co do realizacji trudnego tematu obraz „Kobieta w Berlinie” Maxa Färberböcka z 2008 roku, którego akcja koncentruje się wokół doświadczeń kobiet w ostatnich dniach wojny podczas zdobywania Berlina przez żołnierzy Armii Czerwonej, szczególnie gwałtach wojennych, ale przez reżysera została sportretowana zbyt chaotycznie i melodramatycznie ${ }^{4}$.

Jednak szczególnie duże zainteresowanie w ostatnim okresie budzi temat dziejów Niemieckiej Republiki Demokratycznej. Już w latach dziewięćdziesiątych zeszłego stulecia niemieccy twórcy filmowi podjęli ważki i niełatwy dla swoich rodaków temat, opisując konsekwencje narzuconego, długoletniego podziału kraju na dwa odrębne państwa i dwa odrębne narody. To wówczas powstały produkcje traktujące o tym drażliwym zagadnieniu i o trudnych czasach, takie jak „Legenda Rity” Volkera Schlöndorffa z 2000 roku, „Nie ma dokąd iść” Oscara Rohlera z tego samego roku i „Słoneczna aleja” Leandera Hausmanna z 1999 roku. Ale szczególny rozkwit tej tematyki można było zauważyć na przestrzeni ostatnich dziesięciu lat. Wielkim światowym zainteresowaniem cieszyła się tragikomedia z 2003 roku „Good Bye, Lenin!” Wolfganga Beckera (z fenomenalną

\footnotetext{
${ }^{3}$ Por. E. Fiuk, Nowe niemieckie kino gatunków wobec II wojny światowej, [w:] Kino niemieckie w dialogu pokoleń i kultur, (red.), A. Gwóźdź, Kraków 2004, s. 267-284.

${ }^{4}$ J. Kronsbein, Tränen in rauchenden Trümmern, „Der Spiegel” z 22.10.2008.
} 
grą aktorską Daniela Brühla i Katrin Sass), który w swym dziele starał się uchwycić mieszane uczucia Niemców ze Wschodu - dorosłych już dzieci i ich rodziców - względem komunizmu. Poprzez lekką narrację Becker starał się przedstawić absurdy byłego NRD, ale bez urażania odczuć jego mieszkańców.

Olbrzymi sukces ${ }^{5}$ odniósł również dramat Floriana Henckel von Donnersmarcka „Życie na podsłuchu” z 2006 roku, za który Niemcy ponownie zostali uhonorowani Oscarem dla najlepszego filmu nieanglojęzycznego. Film opisuje niezwykłą relację między nieświadomym założonych $\mathrm{w}$ jego mieszkaniu podsłuchów pisarzem Georgiem Dreymanem, a funkcjonariuszem Ministerstwa Bezpieczeństwa Państwa Gerdem Wieslerem (fantastycznie sportretowanym przez Ulricha Mühe), ideałem marksistowskiego ideologa, człowiekiem bez właściwości, który wydaje się nie żywić do nikogo i wobec niczego żadnych uczuć. Większość bohaterów tego filmu stanowią przedstawiciele czołówki władzy i życia kulturalnego, a reżyser ukazuje dwuznaczne połączenie obu tych środowisk - dziwną wzajemną zależność między aparatczykami SED, którzy rozdają przywileje wedle własnego uznania, ale jednocześnie potrzebują przynajmniej pozorów akceptacji od korzystających z owych przywilejów artystów.

Wart wspomnienia jest także wyświetlany pod koniec 2012 roku na polskich ekranach film „Barbara” Christiana Petzolda, będący niemieckim kandydatem do Oscara, którego skromna fabuła opowiadająca historię granej przez Ninę Hoss lekarki inwigilowanej przez Stasi i uwięzionej z powodu składanych wniosków o pozwolenie na wyjazd do RFN, a następnie przeniesionej z berlińskiego szpitala Charité do niewielkiej nadmorskiej miejscowości, pozwala przyjrzeć się koszmarowi życia w NRD. Jak w swojej recenzji filmu zaznacza Tadeusz Sobolewski „Barbara ukazuje istotną cechę ówczesnego życia, jaką była czujność, ale nie ta "policyjna”, wynikająca ze strachu, tylko międzyludzka, sprzyjająca zaufaniu. Trzeba było zgadywać, z kim się ma do czynienia"'.

W dramacie Petzolda nie chodzi jednak zupełnie o znaną tęsknotę za NRD, tak wyraźnie widoczną w dziele Leandera Haussmanna „Słoneczna aleja" według bestsellerowej powieści Thomasa Brussiga, gdzie życie jest wręcz kolorowe i wesołe, a na porządku dziennym jest nie tylko system, ale i drwina z niego, i która jest też tematem „Good Bye Lenin!” Wolfganga Beckera - w którym syn Alex i córka Ariane Kerner oszukują matkę, entuzjastkę NRD, która przebudziła się ze śpiączki w zjednoczonych już Niemczech. W „Barbarze” ostalgia nie występuje, ale poprzez wyrafinowa-

\footnotetext{
${ }^{5}$ Ale film wywołał też w Niemczech wielkie kontrowersje - czy współpracownik Stasi może być pozytywnym bohaterem?

${ }^{6}$ T. Sobolewski, Film „Barbara”. Piekło, niebo, NRD, „Gazeta Wyborcza” z 12.11.2012.
} 
ne środki przekazu film wskazuje, że i w NRD można było poczuć radość, choćby poprzez niesienie pomocy innym ${ }^{7}$.

Drugim polem zainteresowania niemieckich twórców filmowych jest kwestia społeczeństwa wielokulturowego. Jak podkreślił Adam Trzopek, dyrektor programowy Międzynarodowego Festiwalu Filmu i Muzyki Transatlantyk, gdzie w sekcji Dziesięciu Niemieckich Głosów prezentowano najgłośniejsze tytuły ostatnich lat „Kinematografia niemiecka staje się coraz bardziej wielogłosowa, wynajduje świeże języki do mówienia o starych i nowych niemieckich demonach. Powstają zarówno obrazy epickie, wyestetyzowane, jak i takie, które eksplorują małe ojczyzny, np. berliński Kreuzberg. To kino nie szuka na siłę wspólnego mianownika, a kwitnie pod wpływem kulturowego tygla, tworzonego przez młodych, często pozaniemieckich autorów" ${ }^{\prime \prime}$. I właśnie od przeszło dekady filmy o tureckiej mniejszości, o gastarbeiterach, kręcone przez ich potomków, stały się wizytówką niemieckiego kina artystycznego, dając świeży oddech środowisku skoncentrowanemu na własnych resentymentach. Obecnie nawet trudno mówić o tureckim nurcie w kinie niemieckim jako o osobnej gałęzi kinematografii, bowiem mieszanka problemów, które twórcy (zarówno o niemieckich, jak i wielokulturowych korzeniach) poruszają, weszła na poziom ponadnarodowy.

Wstrząs w Niemczech i Europie wywołał obsypany nagrodami obraz niemieckiego reżysera tureckiego pochodzenia Fatiha Akina "Głową w mur" z 2004 roku, uznany za najlepszy film europejski w tym samym roku, opisujący skomplikowane relacje i oczekiwania wobec życia mieszkających w Republice Federalnej Niemiec Turków. Świetnie zagrani przez Birola Ünela i Sibel Kekilli bohaterowie ukazują historię dwojga życiowych rozbitków, a zarazem środowisko tureckich emigrantów, ich zwyczaje i rolę kobiety w tradycyjnym modelu rodziny. Wnikliwie sportretowane przez reżysera tło społeczne wyróżnia ten film spośród wielu melodramatów, a wykorzystywane niekiedy drastyczne sceny umożliwiają zrozumienie tragizmu sytuacji, w jakiej znalazły się główne postaci. Niewiele mniejsze zainteresowanie wywołał kolejny film Akina „Na krawędzi nieba" z 2007 roku, w którym twórca z Hamburga skonfrontował mentalność turecką z europejską, tworząc portret niemieckich Turków funkcjonujących na przecięciu dwóch kultur. Bohater stworzony

${ }^{7}$ Ciekawym przykładem filmu o czasach NRD i jej końcu jest także najnowsze, dwuodcinkowe dzieło produkcji ARD „Der Turm”, opowiadające o „współczesnych Buddenbrookach" - rodzinie Hoffmann z Drezna, którajest świadkiem upadku Wschodnich Niemiec. W filmie możemy obserwować postawy i zmieniające się światopoglądy poszczególnych członków rodziny.

${ }^{8}$ M. Nowicka, op. cit. 
przez Fatiha Akina pod wszelkimi względami podważa stereotyp słabo wykształconego, niezbyt zamożnego niemieckiego Turka, bowiem Nejat, emigrant drugiego pokolenia, jest wykładowcą germanistyki na uniwersytecie w Hamburgu. Gdy jego owdowiały ojciec przyjmuje na utrzymanie kochankę Yeter, Nejat poznaje skomplikowane życie muzułmanki, która większość zarabianych pieniędzy przesyła córce, studiującej i mieszkającej w Stambule, która aktywnie uczestniczy w antyrządowych demonstracjach z powodu czego musi uciekać z Turcji by uchronić się przed czekającym ją pobytem w więzieniu. I właśnie sportretowanie tej różnicy kultur - paternalistycznej Europy i szukającej swojej tożsamości w świecie XXI wieku Turcji, przyniosło dziełu Fatiha Akina miano Najlepszego Filmu Europejskiego w 2008 rok, a samemu reżyserowi określenie „sumienia" wielokulturowych Niemiec.

Wielkie zainteresowanie publiczności wywołał w 2010 roku dramat o zabójstwach honorowych zatytułowany „Obca”. Film jest debiutem reżyserskim urodzonej w Wiedniu Feo Aladag, która sama jest reprezentantką wielokulturowego społeczeństwa - z pochodzenia jest Austriaczką, ale za mąż wyszła za kontrowersyjnego filmowca o tureckich korzeniach Züliego Aladaga, ma doktorat z psychologii i doświadczenie w marketingu. Jej "Obca" to dramatyczna historia osób, które znalazły się w sytuacji bez wyjścia. Bohaterką jest młoda Turczynka, która postanawia uciec od męża i razem z małym dzieckiem przeprowadza się do mieszkających w Berlinie rodziców. Ale rodzina nie daje jej oparcia - wręcz przeciwnie, obwinia ją o ucieczkę od tradycyjnych wartości i nie dostrzega, iż kobieta walczy o siebie $\mathrm{w}$ zupełnie innych realiach kulturowych, niż te panujące $\mathrm{w}$ Turcji. Siłą obrazu jest postać głównej bohaterki, sugestywnie zagranej przez wspomnianą już Sibel Kekilli, która z jednej strony zyskuje współczucie widzów, jak każda osoba walcząca o prawo do bycia sobą (pragnie móc żyć jak typowa Niemka), a z drugiej strony odpycha, bowiem jej postawa jest mocno egocentryczna. Stawia rodzinę w straszliwie kłopotliwym położeniu i zakłada z góry, że poświęcą dla niej wszystko. Walcząc o swoją wolność, ogranicza wolność innych, w tym swojej siostry, która może stracić ukochanego ze względu na plamę na honorze rodziny ${ }^{9}$. Fabuła oparta została na autentycznej historii mieszkającej w Berlinie Turczynki Hatun Sürücü, która w 2005 roku została zamordowana przez młodszego brata pod pretekstem ochrony honoru rodziny. Postępowanie rodziny i decyzja o przeprowadzeniu honorowego mordu wywołała za Odrą otwartą debatę nad problemem społeczeństwa wielokulturowego i reguł, jakimi kierują

${ }^{9}$ C. Helmcke, Kekilli über ihren neuen Film: "Ich habe geweint”, "Die Welt" z 10.03.2010; Eine türkische Frau auf der Flucht: „Die Fremde”, ibidem z 11.03.2010. 
się mieszkający w RFN imigranci ${ }^{10}$. W swoim dziele reżyserka filmu starała sie przedstawić przede wszystkim kwestię wyczerpania się pojęcia honoru. Jak sama podkreśliła „Obca nie jest reprezentatywnym portretem grupy społecznej ani jej stylu życia. Ten film powinien za to dotkliwie unaocznić pewną sytuację"11.

Zupełnie inaczej tematykę multi-kulti sportretowały natomiast w swoim dziele siostry Yasemin (reżyseria i scenariusz) i Nesrin Samdereli (scenariusz). Ich niezwykle ciepła komedia „Almanya - Witajcie w Niemczech" z 2011 roku opowiada historię trzypokoleniowej tureckiej rodziny, której ojciec przybył do Zagłębia Ruhry z wioski w Anatolii jako 1.000.001 gastarbeiter w latach sześćdziesiątych XX wieku. Jego dzieci urodziły się jeszcze w Turcji ale wnuki już w Europie, a Turcję znają jedynie z opowieści, i nawet z językiem mają kłopoty, a na pytanie „Kim jestem?” słyszą podwójną odpowiedź - „Niemcem”, „Turkiem”. Choć obecnie czują się nad Renem znakomicie, to starszym kraj rodzinny wciąż kojarzy się ze szczęściem i idyllą. Podpatrując swoich bohaterów reżyserka uczy nas, czym są uprzedzenia, strach przed nieznanym i iluzja tego, co zostało zostawione za sobą. W zabawny sposób siostry Samdereli pokazują, jak przed przyjazdem do Niemiec bohaterowie boją się tego, co zastaną w nowym miejscu. Przeraża ich religia i zwyczaje. Jednocześnie będąc już obywatelami Niemiec, nestorzy marzą o choć krótkim powrocie w rodzinne strony. To co ujmuje w tym filmie, to nie tylko humor, ale także brak cynizmu i grania tanimi stereotypami, a jednocześnie trafne ukazanie absurdów życia cudzoziemskich robotników, najpierw zapraszanych przez rząd RFN, potem zostawianych samym sobie. Jak podsumowała dzieło redaktorka tygodnika „Die Zeit” Parvin Sadigh w wywiadzie z autorkami filmu: „Komedia może być bardzo zbawienna, jeśli uwolni się od zatwardziałych stanowisk debaty o integracji lub od strachu przed islamistami i zabójstwami honorowymi"12.

Trzecim obszarem tematycznym, który zajmuje niemieckich kinematografów, jest przedstawienie problemów Niemców w XXI wieku, w czasie globalizacji, ciągłej rywalizacji w życiu zawodowym i prywatnym, w czasie społecznego wyalienowania i popadania w stany depresyjne. Przykładem takiego kina jest obraz Toma Tykwera „Trzy”. Znany na całym świecie dzięki takim dziełom jak „Biegnij Lola, biegnij”, „Pachnidło” czy najnowszemu "Atlasowi chmur" (współreżyseria z rodzeństwem

${ }^{10}$ M. Bartsch, A. Brandt, S. Kaiser, G. Latsch, C. Meyer, C. Schmidt, Haben wir schon die Scharia?, „Der Spiegel” z 26.03.2007.

${ }_{11}$ M. Nowicka, op. cit.

12 "Zu Weihnachten hatten wir einen Plastikbaum", http://www.zeit.de/kultur/film/201102/interview-samdereli-berlinale, data odczytu (10 listopada 2012). 
Wachowski) niemiecki reżyser przygląda się parze czterdziestolatków z Berlina, którzy żyjąc w wolnym, bezdzietnym związku poszukują szczęścia poza wspólnym domem. Zmiana nadchodzi wraz z chorobą mężczyzny i pojawieniem się tego "trzeciego", biologa prowadzącego badania nad komórkami macierzystymi, w którym oboje zakochują się. Duża grupa recenzentów oceniła film jako nieśmieszną utopię o pożytkach z poligamii. I rzeczywiście - jest to pretensjonalny dramat i komedia zarazem, w której humor pojawia się jednak sporadycznie. Ale jest to jednocześnie obraz stanowiący studium miłości u progu trzeciego tysiąclecia ${ }^{13}$.

Ale wśród niemieckich filmów dużo jest przykładów innych, ważnych i dobrze zrobionych dzieł, które poruszają tematy o współczesnych Niemcach, dla których nerwice i depresje są powiązane $\mathrm{z}$ freudowskim źródłem cierpień. „Ponad nami tylko niebo” debiutanta Jana Schomburga z 2011 roku pokazuje, jak idealny świat szczęśliwej żony zamienia się w dramat po śmierci męża, gdy wychodzi na jaw jego podwójne życie. Ale i ona znajduje pocieszenie $\mathrm{w}$ ramionach nowego mężczyzny. Twórca nie ulega jednak hurraoptymizmowi, pokazując labirynty uczuć w późnej nowoczesności, która ocala w ludziach skłonność do kochania, ale nie daje im wiele oparcia w drugiej osobie. „Ponad nami tylko niebo" to opowieść o byciu cząstką świata dla innych lub byciu twórcą własnych marzeń, snów i pragnień. Po jego obejrzeniu, u widza powstają pytania odnoszące się do roli człowieka we współczesnym świecie i znaczenia emocji w nowoczesnym społeczeństwie.

Zupełnie inny wymiar ludzkiego, psychicznego i fizycznego, cierpienia ukazuje natomiast Ralf Huettner w filmie "Vincent chce nad morze" z 2010 roku, gdzie główny aktor a zarazem scenarzysta Florian David Fitz wciela się w chorego na zespół Tourette’a chłopaka, który po śmierci ukochanej matki postanawia uciec z ośrodka dla psychicznie chorych, gdzie umieścił go ojciec, i wspólnie z dwójką zapoznanych w zakładzie przyjaciół jechać do Włoch, by spełnić ostatnie życzenie matki i rozsypać jej prochy na włoskim wybrzeżu. Obraz, uznany za najlepszy niemiecki film 2010 roku, wskazuje jak ważna jest walka o samego siebie, realizacja pasji i nie poddawanie się presji choroby, także tej, która może być wynikiem zaburzeń wynikających ze stresów otaczającego nas świata, jak anoreksja przyjaciółki głównego bohatera.

Podobne, choć inne problemy ukazuje także Andreas Dresen w filmie „W pół drogi” z 2011 roku, który uznany został za najlepszy niemiecki film 2012 roku, a którego fabuła koncentruje się wokół Franka, szczęśliwego męża i ojca, u którego lekarze wykrywają guza mózgu. Zmiana w życiu

${ }^{13}$ W. Höbel, Zu dritt ist man weniger allein, „Der Spiegel” z 20.12.2010. 
spowodowana chorobą wywołuje spustoszenie zarówno $\mathrm{w}$ organizmie mężczyzny, jak i w jego relacjach rodzinnych. „W pół drogi” to wzruszający dramat będący zapisem powolnego odchodzenia i pożegnania ze światem i bliskimi.

Wymienione filmy - „Ponad nami tylko niebo”, „Vincent chce nad morze" $\mathrm{i}$ „W pół drogi” przyniosły wielki sukces niemieckiemu kinu artystycznemu, które ma swoje niezaprzeczalne atuty - są nimi zarówno podejmowana tematyka, zaangażowanie reżyserów oraz dofinansowanie. Jak podkreślił wspomniany już Adam Trzopek „W Niemczech młodych twórców nie tylko dopuszcza się do głosu, ale i promuje. Obiecujący debiutanci nie mają problemów z dystrybucją, a ich filmy są od razu wysyłane na międzynarodowe festiwale. Takiego podejścia możemy się od Niemców uczyć"14.

Ale skutkiem położenia dużego nacisku na film artystyczny realizowany przez twórców młodego pokolenia - choćby niezwykle ciekawe „Combat Girls - Krew i honor" w reżyserii Davida Wnendta z 2011 roku; „Dom na weekend” w reżyserii Hansa-Christiana Schmidta z 2012 roku czy "Joschka i pan Fischer" Pepe Danquarta z 2011 roku - jest odsunięcie na boczny tor niekwestionowanych mistrzów, którzy przez ostatnie dziesięciolecia zdobywali uznanie na całym świecie. Rzadko słychać o filmowych dokonaniach Volkera Schlöndorffa, Wernera Herzoga, Margarethe von Trotta czy Doris Dörrie, którzy często wybierają telewizję i teatr zamiast kina, a etatowy twórca światowych hitów, mieszkający w Stanach Zjednoczonych niemiecki scenarzysta, producent i reżyser Roland Emmerich sam przyznaje, iż jest zmęczony światowym zainteresowaniem i kręceniem przebojów kinowych na zamówienie ${ }^{15}$. Miałkość dzieł niemieckich artystów starszej generacji przełamał w ubiegłym roku jedynie zrealizowany w technice 3D film „Pina” Wima Wendersa, który stał się hołdem złożonym zmarłej w 2009 roku choreografce Pinie (Philippine) Bausch.

Niemieckie kino XXI wieku jest wielowymiarowe, zaskakujące, prowokujące do przemyśleń, czasem obrazoburcze lub pretensjonalne. Wymyka się skatalogowaniu, stąd trudno przedstawić wszystkie wątki podejmowane przez twórców zza Odry. Najbardziej frapujące i najmniej jednoznaczne są obrazy, których twórcy nie kryją się za parawanem historii czy krytyki postkolonialnej mentalności, a próbują uchwycić w locie współczesnego człowieka, niemniej również studia nad psychiką Niemców w okresie lat 1933-1945 i w czasie istnienia NRD są niezwykle ciekawe. Niemiecka kinematografia jest obecnie przykładem doskonałego współdziałania państwa, biznesu i artystów, a ilość produkowanych

${ }^{14}$ M. Nowicka, op. cit.

${ }^{15}$ M. U. Müller, T. Tuma, Das Starsein ist furchtbar, „Der Spiegel” z 08.08.2011. 
u naszych zachodnich sąsiadów dzieł (około 200 rocznie) może zawstydzać. Choć Niemcy uwielbiają produkcje zagraniczne, często i chętnie odwiedzają sale kinowe celem obejrzenia rodzimej twórczości. Może więc i problemy poruszane $\mathrm{w}$ filmach są dla nich ciekawe i ważne?

\section{Zusammenfassung}

Im Artikel wird auf das Thema des deutschen Films im 21. Jahrhundert hingewiesen und dabei aufgezeigt, auf welche Problematik sich deutsche Filmemacher heute hauptsächlich konzentrieren. Die Autorin des Textes hebt die Tatsache hervor, dass zahlreiche Regisseure in ihren Werken geschichtliche Kontexte thematisieren - im Vordergrund steht oft die Zeitgeschichte und deren Schwerpunkte: der Nationalsozialismus, Trennung der deutschen Nation in den Jahren 1949-90, Erfahrungen und Schicksale der Bürger, der Alltag in der wiedervereinigten Republik, die Frage der Integration der multikulturellen Gesellschaft sowie die der aktuellen Herausforderungen, vor welchen die zeitgenössische deutsche Gesellschaft steht.

Die Autorin fokussiert auf bedeutendste Werke der deutschen Kinematographie der letzten Dekade und bespricht u.a. die weltbekannten Filme: „Der Untergang“ von Oliver Hirschbiegel, "Good Bye, Lenin!“" von Wolfgang Becker, "Gegen die Wand“ und „Auf der anderen Seite" von Fatih Akin, "Almanya - Willkommen in Deutschland" von Yasemin und Nesrin Samdereli, "Drei“ von Tom Tykwers sowie Andreas Dresens „Halt auf freier Stecke“. Dem Artikel sind auch eine kritische Darstellung der Filme wie auch die Schlussfolgerung zu entnehmen, dass das gegenwärtige deutsche Kino ein hervorragendes Beispiel für die Zusammenarbeit von Staat, Wirtschaft und Künstlern ist. 